Article

\title{
Effects of Microbial Inoculants on the Fermentation and Preservation of Triticale Silages at High and Low Moisture Levels
}

\author{
Ilavenil Soundharrajan ${ }^{1}$, Karnan Muthusamy ${ }^{1}$, Ouk-Kyu Han ${ }^{2}$, Hyun Jeong Lee ${ }^{3}$, \\ Sumitha Purushothaman ${ }^{4}$, Dahye Kim ${ }^{5}$ and Ki Choon Choi ${ }^{1, * \mathbb{D}}$ \\ 1 Grassland and Forage Division, National Institute of Animal Science, RDA, Cheonan 31000, Korea; \\ ilavenil@korea.kr (I.S.); karnantm111@gmail.com (K.M.) \\ 2 Department of Crop Science, Korea National College of Agriculture and Fisheries, Jeonju 54874, Korea; \\ okhan98@korea.kr \\ 3 Jangsu Agriculture Technology Center, Jangsu, Jeollabuk-do 55640, Korea; leehj5328@korea.kr \\ 4 Department of Biotechnology, Bharathidasan University, Tiruchirappalli 620024, Tamilnadu, India; \\ gpsumitha@gmail.com \\ 5 Faculty of Biotechnology, College of Applied Life Science, Jeju National University, Jeju 63243, Korea; \\ pioioiq@nate.com \\ * Correspondence: choiwh@korea.kr; Tel.: +82-41-580-6752; Fax: +82-41-580-6779
}

Received: 25 September 2020; Accepted: 3 November 2020; Published: 5 November 2020

\begin{abstract}
In the current study, Lactobacillus rhamnosus (KCC-51) and Lactobacillus paracasei (KCC-52) were isolated and investigated for their biological potential including antibacterial activity, probiotic potential, nutritional changes, fermentation ability, and microbial population in experimental silages at high moisture (HM) and low moisture (LM) conditions. These strains showed significant antibacterial activity and probiotic activities. There are no significant changes in the dry matter content (DM) and nutritional profiles of control, KCC-51, and KCC-52 treated silages. High lactic acid (LA) and low butyric acid (BA) levels were noted in the HM (LA: $4.82 \pm 0.34$ and $5.5 \pm 0.03$, BA: $0.01 \pm 0.01$ and $0.008 \pm 0.001, \% \mathrm{DM}$ ) and LM (LA: $2.27 \pm 0.32$ and $2.61 \pm 0.2$, BA: $0.017 \pm 0.001$ vs. $0.006 \pm 0.05, \% \mathrm{DM}$ ) silages treated with KCC-51 and KCC-52 respectively, compared to non-inoculated silages. KCC-51 and KCC-52 treatment increased acceptable range of acetic acid (AA) in HM $(0.33 \pm 0.02$ and $0.24 \pm$ $0.007, \% \mathrm{DM})$ and $\mathrm{LM}(0.22 \pm 0.007$ and $0.35 \pm 0.02, \% \mathrm{DM})$ silages compared to non-inoculated silages $(0.22 \pm 0.03$ and $0.17 \pm 0.05, \% \mathrm{DM})$. Rich $\mathrm{LAB}$ and low yeast counts were noted in the silages treated with KCC-51 and KCC-52, it indicated that the addition of these inoculants strongly dominated the enterobacterial growth and preserved the silage quality with essential metabolites. It suggests that L. rhamnosus and the L. paracasei could be used as potent inoculants for the silage production with enriched nutrients.
\end{abstract}

Keywords: L. paracasei; L. rhamnosus; probiotics; triticale silage; low and high moistures

\section{Introduction}

Ensiling is an essential process which is used to preserve the plant raw material plant material by spontaneous lactic acid production under controlled fermentation process with an anaerobic condition which has been used in the preservation of forages for many decades [1]. This method has gained great attention worldwide to deliver consistent and predictable feed supply to the ruminants. Loss of nutrients by aerobic oxidation of plants, undesirable microbial dynamics in plants, proteolytic activity, and unwanted fermentation by clostridia, amino acid deamination, and decarboxylation could negatively affect the conservation of forages which elevates energy and nutrient losses and 
accumulates anti-nutritional compounds in forage samples [2,3]. Grass and legumes intended for silages which have different types of aerobic and anaerobic microbial dynamics on their surface are called epiphytic microflora. It has been varied based on the types of raw materials [4]. The abundance of microflora in the plant parts consist of different types of lactic acid bacteria (LAB) and other microbial diversity as the point of the silage fermentation and their quality. The LAB in the forages can utilize the plant water-soluble carbohydrates and convert into lactic acid [5] with less level of acetic acid which enhances the acidification of silages and control or inhibits the growth of undesirable microbes including yeast and molds and it allows for long time storage. The relative abundance of LAB in the native plants when ensiled is not enough to initiate the favorable fermentation products, mainly lactic acid level; a major acid has been produced in the silages by LAB [6]. Ben Dov et al. reported that the LAB in the plants is often heterofermentative and low in number [7]. It increases the ration of lactic acid into other metabolites such as acetic acid, and ethanol, but homo-fermentative bacteria could not have the ability to convert lactic acid into other products, it sustained high level of the lactic acid level in silages, an indicator of quality silages. Production of high-quality silages with strong digestibility requires induction of the fermentation in ensiled silages by addition of different types of additives, particularly $\mathrm{LAB}$, has got great attention to use as additives due to its efficient production of lactic acid without any harmful effects to ruminants. The expected changes in silage production when ensiled with LAB increases in the ratio of lactic acid with marginal amounts of acetic acid, reduction in proteolysis and increased dry matter recovery [4]. Dominant species involved in the fermentation process of silage are Lactobacillus, Pedioccous, and Lactococcus, the genus of lactobacillus such as L. plantarum, L. brevis, L. casei, L. rhamanosus, L. curvatus, L. gasseri, L. pentosus, and the genus of pedococcus including P. pentosaceus, P. acidilactici, P. damnosus, P. confusa were noted in the silage samples $[1,8,9]$. L. casei, L. paracasei, and L. rhamnosus are phylogenetically and phenotypically closely related $[10,11]$. These species have the ability to colonize a variety fermented food products representing dominant component of non-starter LAB in ripened cheeses and traditional fermented milk products [12-15] such as fermented vegetables [16] and kimchi [17]. In addition, these strains have been used as starter culture in milk fermentation as adjunct cultures for intensification and proven their probiotics features [18,19]. Additionally, L. paracasei and L. rhamnosus could be considered as excellent additives for plant based silage production with enriched nutrients for ruminant and non-ruminants [20-23].

Triticale is a breed plant between wheat (Triticum) and rye (Secale). It has rich crude protein content and high resistance against many diseases and other environmental factors (Natasa et al., 2018). Triticale has been used as a primary meal for the poultry, ruminants and non-ruminants due to its nutritional values [24]. Replacement of corn silage with triticale and wheat at $10 \%$ of the diet dry matter (DM) did not affect DM intake, but decreased milk yield and its components compared to corn silage. At the same time, milk fat from alternative forage diet had a higher level of 4:0, 6:0, and 18:0 and the lower concentration of total trans-fatty acids. Digestibility of neutral and acid detergent fiber was increased in triticale silage diet. Emission of methane was higher for triticale and $\mathrm{CO}_{2}$ was reduced by both triticale and wheat silages, concluded that triticale or wheat double cropped with corn many be providing significant cropping strategy [25]. Triticale is one of the available options for swath grazing to extend the fall grazing and produce as silage or hay for beef cattle producers in Canada [26]. Ensiling of pre-mature cereal of barley, wheat, triticale, and rye with LAB could serve as alternative forages [27]. Triticale has an excellent impact on higher meat production as well as gives good responses for dairy and sheep milk production in Algeria [28]. Few reports have been available on the improvement of nutritional values of triticale silages using LAB; recently many researchers have been focused on silage production using triticale plant and LAB due to its crude proteins and positive fermentative capabilities, respectively. Thus, the production of high-quality silage from early heading and heading stages of triticale is a good source due to its rich crude proteins. The use of LAB as an inoculum has been proposed as effective strategies to improve feed palatability and be stored for prolonged periods. In the current study, we isolated effective Lactobacillus strains (Lactobacillus 
rhamnosus and Lactobacillus paracasei) and demonstrated its potential effects on fermentation of triticale at different moistures. Furthermore, probiotic potential was also studied.

\section{Materials and Methods}

\subsection{Isolation and Characterization of Lactic Acid Bacteria}

Triticale sample was collected at different places of the same land from Jangsoo, Korea (Latitude: 35.6185318 and longitude: 127.5107881) in 2018 and transferred aseptically to the laboratory for isolation of effective LAB stains by tenfold serial dilution with sterile distilled water. Man Rogosa and Sharpe agar medium (MRS agar) were used to isolate LAB colonies, and identity was confirmed in Bromo cresol purple agar medium (BCP agar). Further, 16srRNA sequences and NCBI blast tools were used to determine the species of LAB at the genomic level. Antibiotic sensitivity $[29,30]$, carbohydrates fermentation test, and extracellular enzymes secretion were confirmed by API-CH50 and API-ZYM kits, Marcy-I'Etoile, France, respectively. Antibacterial activity of LAB extracellular metabolites (well diffusion, time-killing assay against E. faecalis, E. coli, P. aeruginosa, and S. aureus) and probiotic characterizations (survival rates in gastric, duodenal and Intestinal Juices, Hydrophobicity, auto-aggregation and Co-aggregation) of strains also studied according to previously published research [29]. All LAB colonies were maintained in MRS agar plats and 20\% glycerol solution for short and long-term storage, respectively.

\subsection{Bacterial Cultivation and Enumeration}

Lactobacillus species were inoculated in MRS broth (CONDA, Madrid, Spain) and incubated at 32 ${ }^{\circ} \mathrm{C}$ for $24 \mathrm{~h}$. One $\mathrm{mL}$ culture was taken and centrifuged at $4000 \times \mathrm{g}$ for $10 \mathrm{~min}$, and the supernatant was discarded. Pellet was washed thrice with phosphate-buffered saline (PBS, pH 7.4). The bacterial colonies were counted with the help of QUANTOM ${ }^{\mathrm{TM}}$ viable cell staining method (Logos biosystem, Gyeonggi-do, Korea). In brief, the pellets were diluted in QUANTOM $^{\mathrm{TM}}$ viable cell dilution buffer. $10 \mu \mathrm{L}$ diluted bacterial culture mixed with $2 \mu \mathrm{L}$ QUANTOM $^{\mathrm{TM}}$ viable cell staining dye and then incubated at $37^{\circ} \mathrm{C}$ for $30 \mathrm{~min}$ in the dark place. Further, $8 \mu \mathrm{L}$ QUANTOM ${ }^{\mathrm{TM}}$ cell loading buffer and mix gently without create bubbles. After that, $6 \mu \mathrm{L}$ of the sample was loaded onto a QUANTOM ${ }^{\mathrm{TM}}$ M50 cell counting slide and centrifuged at $300 \times g$ for $10 \mathrm{~min}$ in QUANTOM ${ }^{\mathrm{TM}}$ centrifuge. The bacterial colonies were counted with a QUANTOM ${ }^{\mathrm{TM}}$ with the light intensity level set to 9 for most bacterial cells. Harvesting bacteria for silage production, culture was centrifuged and washed with PBS and then diluted in sterile distilled water (final concentration, $1 \times 10^{4} / \mathrm{mL}$ ).

\subsection{Triticale Silage Production with an Ensiled Method}

We harvested Joseong cultivar triticale at the heading stage from Jangsoo, Chunbuk (Latitude: 35.6185318 and longitude: 127.5107881 ), Korea in the 2019 and allowed to wilt in the filed for 8-10 $\mathrm{h}$ for high moisture and 24-36 h for low moisture silage productions. $300 \mathrm{~g}$ of triticale from each stage was chopped to a theoretical cut of 1.5-2.5 with forage cutter. Samples were packed in a silage bag size $28 \times 36 \mathrm{~cm}$ (Aostar Co., Ltd., Seoul, Korea). Experiments were randomly divided into three groups from each moisture (Higher and low) contain five replicates. The experimental groups were group-I control (Non-Inoculated, $3 \mathrm{~mL}$ water only), Group-II samples inoculated with L. rhamnosus $\times 10^{4} \mathrm{CFU} / \mathrm{mL}(1 \mathrm{~mL}$ inoculum and $2 \mathrm{~mL}$ water); Group-III samples inoculated with L. paracasei $\times$ $10^{4} \mathrm{CFU} / \mathrm{mL}$ ( $1 \mathrm{~mL}$ inoculum and $2 \mathrm{~mL}$ water). The air was evacuated from all bags by a vacuum sealer (Food saver V48802, MK Corporation, Seoul, Korea). A total of 30 bags were prepared and stored at laboratory conditions for 180 days. After opening at day 180 , the $\mathrm{pH}$ and nutrient profiles such as $\mathrm{CP}$, ADF (AOAC, 2000), NDF (Van Soest et al., 1991), and TDN (TDN = 89.9 - $\left.\left(\mathrm{ADF}^{*} 0.79\right)\right)$ contents of silage were determined. 


\subsection{Quantification of Fermentative Metabolites and Microbial Enumeration in Ensiled Silages}

Ten grams of each silage sample was mixed in $90 \mathrm{~mL}$ sterile water in a lab blender for $3 \mathrm{~min}$. The extract was filtered through double layers of sterilized cheesecloth and divided into three portions. Portion-I-The $\mathrm{pH}$ of the samples was measured with a calibrated $\mathrm{pH}$ meter (lab $\mathrm{pH}$ meter, Thomas Scientific, Swedesboro, NJ, USA). Portion-II was used to the quantification of fermentative metabolites such lactic acid, acetic acid, and butyric acid by High performance Liquid Chromatography system [30] (HP1100 Agilent Co., Santa Clara, CA, USA). Portion-III used of enumeration of total bacteria, LAB, molds, and yeast. Tenfold serial dilution of water extracts was done in sterile distilled water. A hundred microliters of each sample were poured onto MRS agar for lactic acid bacteria; onto nutrient agar for total bacteria and $1 \mathrm{~mL}$ onto petriflim for yeast and molds counts enumeration (3M Microbiology Products, USA) and incubated at $30 \pm 2{ }^{\circ} \mathrm{C}$ ( $48 \mathrm{~h}$ for LAB and $72-120 \mathrm{~h}$ for yeast and mold). QUANTOMTM livecell staining kit was used to enumerate the total bacteria in the samples, as discussed earlier.

\subsection{Statistical Analysis}

The experiment was a randomized design with two treatments and five replicates per treatment. Significant differences between control and experimental samples were analyzed with SPSS16 software using analysis of variance (one-way ANOVA, multivariate analysis, included post hoc, Duncan and descriptive analysis parameters), followed by the least significance difference test. $p$-value of less than 0.05 was considered as statistically significant.

\section{Results}

\subsection{Biochemical Characterization}

The potent Lactobacillus strains were isolated and selected based on its antimicrobial activity, from triticale forage samples and characterized its physicochemical properties which reflect, these strains are gram-positive, rod-shaped, and catalase-negative with non-motile characteristic. 16srRNA sequences and NCBI analysis output revealed that these lactobacillus strains belonged to Lactobacillus rhamnosus and Lactobacillus paracasei which were labelled as L. rhamnosus KCC-51 and L. paracasei KCC-52 (Supplementary Table S1). The sequences of these strains were deposited into NCBI database (GenBank Accession Numbers MW015793 and MW015794). KCC-51 and KCC-52 fermented different carbohydrate substrates at various levels (Supplementary Table S2). We noted these strains secreted various enzymes which have many applications in food and leather industries (Supplementary Table S3). An antibiotic sensitivity test is essential for the selection of potent probiotic strains; the data suggest that both strains had strong sensitivity against almost all the tested antibiotics (Supplementary Table S4).

\subsection{Antibacterial Activity}

Then, we investigated the effect of extracellular supernatant (ECS) of KCC-51 and KCC-52 on the viability of pathogenic bacteria by well-diffusion and time-dependent killing assay methods. ECS of both strains exhibited significant antibacterial activity against E. faecalis, E. coli, P. aeruginosa, and $S$. aureus. CFS of KCC-51 showed maximum inhibitory zone against $E$. coli and the very less inhibitory zone was noted against aureus, P. aeruginosa, and S. aureus. However, KCC-52 exhibited strong inhibitory zone against. S. aureus, E. coli, P. aeruginosa and, to a lesser extent, S. aureus (Table 1). Next, we determined antibacterial activity of lyophilized CFS of KCC-51 and KCC-52 in a concentration and time-based inhibition of pathogenic bacterial growths. The pathogenic bacteria treated with different concentrations of lyophilized CFS of both strains and incubated for $48 \mathrm{~h}$. Time-dependent analysis showed that the CFS treatment at the different concentrations $(1.25-20 \mathrm{mg} / \mathrm{mL})$ inhibited the growth of pathogenic bacterial. All bacterial growth was reduced when increased concentration of CFS of KCC-51 (Figure 1) and KCC-52 (Figure 2). 
Table 1. Antibacterial activity of extracellular supernatant (ECS) of KCC-51 and KCC-52 against various pathogens by well diffusion method.

\begin{tabular}{ccc}
\hline \multirow{2}{*}{ Pathogenic Bacteria } & \multicolumn{2}{c}{ Zone of Inhibition (mm) } \\
\cline { 2 - 3 } & L. rhamnosus KCC-51 & L. paracasei KCC-52 \\
\hline E. faecalis & $6.30 \pm 1.1$ & $26.6 \pm 1.5$ \\
E. coli & $22.3 \pm 3.0$ & $28.6 \pm 3.2$ \\
P. aeruginosa & $5.60 \pm 0.5$ & $19.6 \pm 1.5$ \\
S. aureus & $5.30 \pm 1.2$ & $12.0 \pm 2.0$ \\
\hline
\end{tabular}

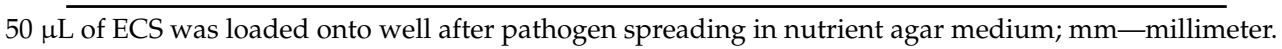

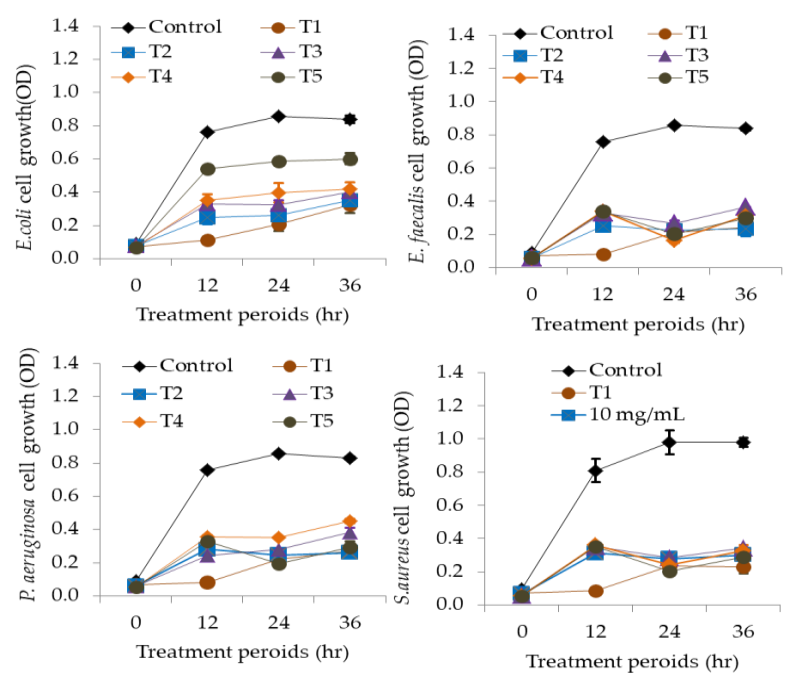

Figure 1. Antibacterial activity of lyophilized ECS of KCC-51 at the different concentrations and time incubation. Data are expressed as the mean \pm S. E.M. of five replicates. The analysis was performed with three technical replicates from each sample. T1 $-20 \mathrm{mg} / \mathrm{mL}, \mathrm{T} 2-10 \mathrm{mg} / \mathrm{mL}, \mathrm{T} 3-5 \mathrm{mg} / \mathrm{mL}$, $\mathrm{T} 4-2.5 \mathrm{mg} / \mathrm{mL}$, and T5-1.25 mg/mL of lyophilized ECS.
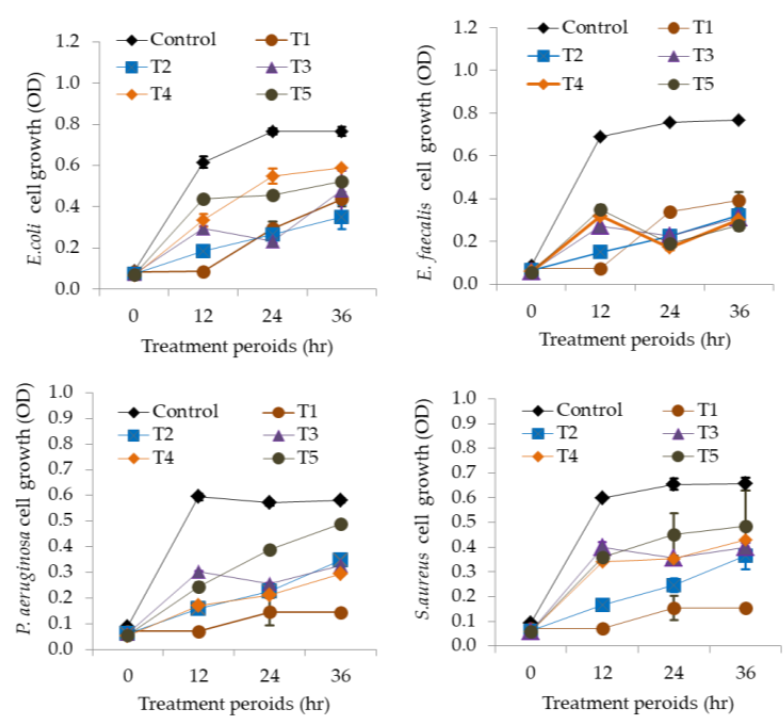

Figure 2. Antibacterial activities of lyophilized ECS of KCC-52 at the different concentrations and incubation periods. Data are expressed as the mean \pm S. E.M. of five replicates. The analysis was performed with three technical replicates from each sample. T1-20 mg/mL, T2-10 mg/mL, T3-5 mg/mL, T4-2.5 mg/mL and T5-1.25 mg/mL of lyophilized ECS. 


\subsection{Probiotic Characterization}

Since KCC-51 and KCC-52 showed good antibacterial activity, we determined its probiotic potential, which included survival ability in the gastrointestinal tract (GIT) conditions, hydrophobicity, and aggregation properties. Here, we used simulated GIT juices (Gastrointestinal, Duodenal and intestinal juices) to determine the survival capability of both strains in GIT condition, an essential criterion for the selection of best probiotic strain, data suggested that both strains could have significant survival rates in harsh conditions of GIT after 3h incubation (Figure 3a). The hydrophobicity of these strains in apolar solvent xylene and polar acidic solvent chloroform was determined. KCC-51 (52.5\% vs. $63.4 \%)$ showed a comparatively higher affinity with xylene compared to KCC-52 $(45.4 \%$ vs. $53.9 \%$ ) at all incubation periods ( $30 \mathrm{~min}$ vs. $60 \mathrm{~min}$ ). The affinity of strains with hydrocarbons was increased when prolonged incubation. KCC-51 and KCC-52 had a higher affinity with xylene compared to chloroform (Figure 3b). Auto-aggregation of both strains was studied on the basis of their sedimentation characteristics and clear solution development (Figure 3c). These strains had a higher auto-aggregation property $(>70 \%)$ at $90 \mathrm{~min}$ incubation. However, KCC-51 (45.4 \pm 2.6 vs. $58.4 \pm 5.9$ vs. $80.5 \pm 0.8 \%$ ) showed higher auto-aggregation capability from beginning to end of the incubation periods $(30,60$, and $90 \mathrm{~min})$ compared to KCC-52 ( $38.1 \pm 5.8$ vs. $49.8 \pm 3$ vs. $71.9 \pm 2.5 \%$ ). The co-aggregation study indicated that both strains had similar co-aggregation capacity with $E$. coli in a time-dependent manner (Figure 3d).
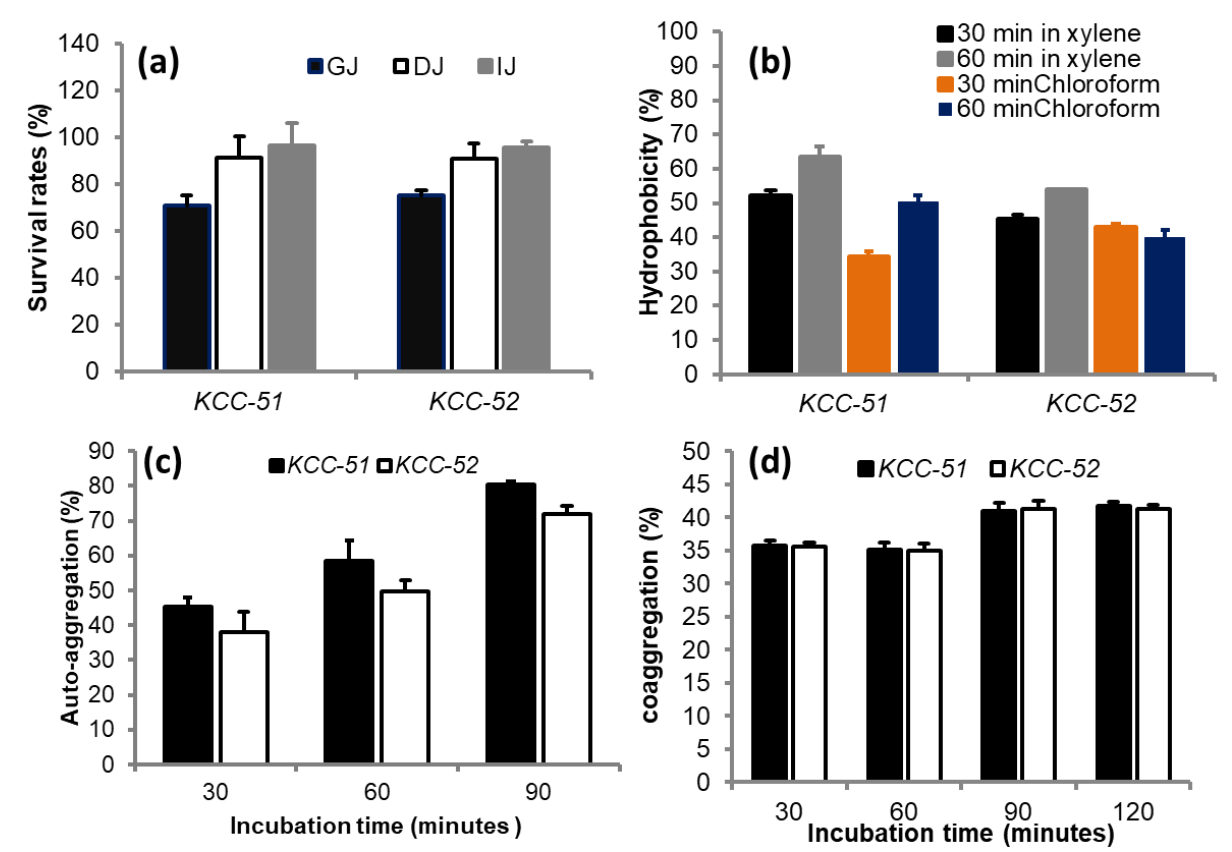

Figure 3. Probiotic features of KCC-51 and KCC-52. (a) Survival ability in simulated gastric juice (GJ), duodenal juice (DJ) and intestinal juice (IJ); (b) hydrophobicity property of KCC-51 and KCC-52 in xylene and chloroform; (c) auto-aggregation of strains; (d) co-aggregation of ability of KCC-51 and KCC-52 with E. coli. Data are expressed as the mean \pm S. E.M. of three replicates. Analysis was performed with three technical replicates from each sample.

3.4. Effects of Inoculants KCC-51 and KCC-52 on Microbial Community Dynamics, Nutrient and Fermentative Metabolites Profiles in Triticale Silage at High and Low Moistures

\subsubsection{Nutrient Compositions and $\mathrm{pH}$ of the Silages}

At day 180 we determined nutrient profiles and silages $\mathrm{pH}$ in non-inoculated and inoculated silages, the results indicated that the addition of inoculants did not affect the dry matter (DM) and nutrient contents (CP, ADF, NDF, and TDN) of triticale silages (Table 2). Non-inoculated silages of 
both high ( $\mathrm{pH}$ 6.12) and low moistures ( $\mathrm{pH}$ 5.85) had higher $\mathrm{pH}$ level which reflects the indigenous $\mathrm{LAB}$ in the plant is not sufficient to reduce $\mathrm{pH}$ of the silages suggested that native LAB in the plant could not have the ability to enhance the fermentation when ensiled condition. However, the addition of inoculants KCC-51 and KCC-52 (High moisture: $\mathrm{pH} 4.29$ vs. 4.18 and low moisture: $\mathrm{pH} 4.62$ vs. 4.71) lowered $\mathrm{pH}$ of the high and low moistures silages of triticale compared to non-inoculated silages (pH 6.12 vs. $5.85 ; p<0.05$ ).

Table 2. Nutritional contents (\%) and fermentative characteristics (\%DM) of low and high moistures silages of triticale in non-inoculated and inoculated (KCC-51 and KCC-52) silages of triticale at high and low moistures.

\begin{tabular}{|c|c|c|c|c|c|c|}
\hline \multirow[t]{2}{*}{ Items } & \multicolumn{3}{|c|}{ High Moisture } & \multicolumn{3}{|c|}{ Low Moisture } \\
\hline & Control & KCC-51 & KCC-52 & Control & KCC-51 & KCC-52 \\
\hline $\mathrm{pH}$ & $6.14 \pm 0.03^{a}$ & $4.29 \pm 0.05^{b}$ & $4.18 \pm 0.03^{b}$ & $5.85 \pm 0.03^{a}$ & $4.62 \pm 0.11^{b}$ & $4.71 \pm 0.07^{b}$ \\
\hline DM & $37.1 \pm 0.56$ & $38.1 \pm 1.3$ & $38.4 \pm 0.91$ & $58.4 \pm 0.43$ & $58.2 \pm 0.67$ & $58.50 \pm 0.77$ \\
\hline \multicolumn{7}{|c|}{ Nutrient compositions (\%) } \\
\hline $\mathrm{CP}$ & $15.9 \pm 0.51$ & $15.8 \pm 0.14$ & $15.6 \pm 0.25$ & $15.0 \pm 0.01$ & $15.3 \pm 0.12$ & $14.9 \pm 0.15$ \\
\hline $\mathrm{ADF}$ & $35.5 \pm 0.43$ & $34.7 \pm 0.31$ & $35.4 \pm 0.25$ & $35.0 \pm 0.23$ & $35.1 \pm 0.27$ & $34.7 \pm 0.32$ \\
\hline NDF & $61.3 \pm 0.37$ & $60.6 \pm 0.96$ & $61.3 \pm 0.38$ & $61.5 \pm 0.18$ & $62.5 \pm 0.20$ & $61.3 \pm 0.51$ \\
\hline TDN & $61.8 \pm 0.34$ & $62.4 \pm 0.25$ & $61.9 \pm 0.20$ & $62.2 \pm 0.18$ & $62.1 \pm 0.21$ & $62.3 \pm 0.25$ \\
\hline \multicolumn{7}{|c|}{ Fermentation products (\% DM) } \\
\hline LA & $0.04 \pm 0.01^{b}$ & $4.82 \pm 0.34^{\mathrm{a}}$ & $5.5 \pm 0.03^{\mathrm{a}}$ & $0.05 \pm 0.01 \mathrm{~b}$ & $2.27 \pm 0.32^{\mathrm{a}}$ & $2.61 \pm 0.2^{\mathrm{a}}$ \\
\hline AA & $0.22 \pm 0.03^{b}$ & $0.33 \pm 0.02^{\mathrm{a}}$ & $0.24 \pm 0.007^{b}$ & $0.17 \pm 0.05^{b}$ & $0.22 \pm 0.007^{b}$ & $0.35 \pm 0.02^{a}$ \\
\hline BA & $0.06 \pm 0.01^{\mathrm{a}}$ & $0.01 \pm 0.01 \mathrm{~b}$ & $0.008 \pm 0.001^{b}$ & $0.027 \pm 0.00^{\mathrm{a}}$ & $0.017 \pm 0.001 \mathrm{~b}$ & $0.006 \pm 0.05^{c}$ \\
\hline LA/AA & $0.16 \pm 0.03^{c}$ & $14.6 \pm 1.43^{b}$ & $22.6 \pm 0.65^{\mathrm{a}}$ & $0.30 \pm 0.04^{c}$ & $10.35 \pm 1.18^{\mathrm{a}}$ & $7.42 \pm 0.47^{b}$ \\
\hline
\end{tabular}

\subsubsection{Fermentative Metabolites}

As KCC-51 and KCC-52 exhibited a substantial reduction in $\mathrm{pH}$ of silages, then we quantified major fermentative acids found in the ensiled silages of both non-inoculated and inoculated silages, Non-inoculated high and low moistures silages of triticale had a lower level of lactic acid (high: 0.04 vs. low: $0.07 \mathrm{DM} \%$ lactic acid) and a higher level of butyric acid (high: 0.06 vs. low: $0.02 \mathrm{DM} \%$ butyric acid) which indicates native bacteria in the plant is not enough to induce the fermentation process and fail to reduce the $\mathrm{pH}$ of silages under controlled conditions. However, the addition of KCC-51 and KCC-52 sharply increased content lactic acid with a marginal amount of acetic acid in both high and low moisture silages, which means our inoculants treatment enhanced successful fermentation and the acidification of silages. Addition of KCC-51 and KCC-52 slightly increased acetic acid levels $(0.22$ vs. $0.35 \mathrm{DM} \%$ acetic acid) in low moisture silages compared to control silage (0.20 DM\%). In higher moisture silage, KCC-51 treatment slight increased acetic acid content compared to control, whereas high moisture silage inoculated with KCC-52 showed lower acetic acid content compared to control and KCC-51 (Table 2).

\subsubsection{Microbial Populations}

Lower total bacteria and lactic acid bacteria (LAB) and higher yeast counts were noted in non-inoculated silages; it is the key reason behind the less concentration of lactic acid level in non-inoculated silages compared to inoculums applied silages. In contrast, higher total bacteria and LAB with lower yeast counts were recorded in the silages treated with KCC-51 and KCC-52 (Table 3). Mold counts were not detected in both non-inoculated and inoculated silages of triticale. 
Table 3. Microbial populations of low and high moistures silages of triticale in non-inoculated and inoculated (KCC-51 and KCC-52) silages of triticale at high and low moistures.

\begin{tabular}{|c|c|c|c|c|c|c|}
\hline \multirow[t]{2}{*}{ Items } & \multicolumn{3}{|c|}{ High Moisture } & \multicolumn{3}{|c|}{ Low Moisture } \\
\hline & Control & KCC-51 & KCC-52 & Control & KCC-51 & KCC-52 \\
\hline \multicolumn{7}{|c|}{ Microbiology $\left(\log 10 / g^{-1}\right)$} \\
\hline TB & $8.76 \pm 0.02^{b}$ & $9.85 \pm 0.03^{a}$ & $9.85 \pm 0.12^{\mathrm{a}}$ & $8.73 \pm 0.03^{c}$ & $9.65 \pm 0.03^{b}$ & $9.80 \pm 0.03^{a}$ \\
\hline LAB & $7.34 \pm 0.02^{b}$ & $8.47 \pm 0.03^{a}$ & $8.79 \pm 0.12^{a}$ & $7.27 \pm 0.03^{c}$ & $8.62 \pm 0.03$ & $8.76 \pm 0.02$ \\
\hline Yeast & $5.32 \pm 0.04^{\mathrm{a}}$ & $4.45 \pm 0.16^{b}$ & $4.32 \pm 0.07^{b}$ & $5.66 \pm 0.04$ & $4.96 \pm 0.05$ & $5.07 \pm 0.04$ \\
\hline Mould & ND & ND & ND & ND & ND & ND \\
\hline
\end{tabular}

TB: Total bacteria; LAB: Lactic acid bacteria; ND: not detected. Data are expressed as the mean \pm S. E.M. of five replicates, counting analysis was performed with three technical replicates from each sample. ${ }^{a, b, c} p<0.05$ alphabets within columns indicate significant differences between experimental silages.

\section{Discussion}

Triticale is a breed plant generated by crossing wheat and rye, it is the first successfully obtained grain from two different grain plants, and it is used in the diet of domestic and farm animals by different ways. It has a high content of crude protein as well as carbohydrates which are the key factors for the production of concentrated animal feed. It can replace oats, fodder, barley, and other cereals [24]. Preservation of forages with rich nutrients for prolonged periods is challengeable due to loss of nutrients by plant oxidation, entero-bacteria growths, proteolytic activity, undesired fermentation, deamination and decarboxylation of amino acids strongly affects the quality of forage/silage which increases energy loss and anti-nutritional compounds in the forages [3]. The major objectives of the silage and feed industry are to improve the nutritional content, aerobic stability, and absorbance efficiency of plant silages. In general, lactic acid bacteria (LAB) plays a major role in the preservation of forages at ensiled condition by rapid induction of fermentation of silages. However, in the feed industry, indigenous LAB population in the plant is not sufficient to meet the current industry requirements. Therefore, additional inoculums are required to make good quality silages with preserved nutrients, particularly LAB. In the current study, potent lactic acid bacteria were isolated and identified by biochemical and molecular tools indicated that these strains belonged to the L. rhamnosus and L. paracasei. These bacteria were able to ferment various carbohydrates substrates which varied among the strains and it produces different kind extracellular enzymes which are very useful in food and leather industries. These enzymes productions differed between the KCC-51 and KCC-52, it consisted with a previous report [31]. Antibiotic sensitivity of LAB is an essential criterion for the selection of potent probiotic strains. The isolated KCC-51 and KCC-52 possess good antibiotic sensitivity against almost all of the tested antibiotics, but slightly varied among the antibiotics [32]. In addition, KCC-51 and KCC-52 had greater antibacterial activity against E. faecalis, E. coli, P. aeruginosa, and S. aureus, which could be very useful in the prevention of pathogenic/undesirable microbial growths. Most of the LAB showed significant antibacterial activity against E. coli, S. enteritidis, S. aureus, and E. faecalis [29,33]. As a good probiotic, strains must have strong antimicrobial activity, survive in the harsh condition of GIT such as resistant in gastric, duodenal intestinal juices, hydrophobicity and aggregation properties [34,35]. Here we noted significant survival rates of both strains in the simulated gastric, duodenal, and intestinal juices. Strains were reduced initially in the gastric juice due to its lower acidic condition similar to the stomach, further transferring of these strains into the duodenal and intestinal juices showed more survival rates compared to gastric juice; it suggested that these strains obtained strong resistance capacity from low $\mathrm{pH}$ of the gastric juice. Bile salt and higher $\mathrm{pH}$ affect the probiotic growths [36,37]. Moreover, the probiotic features have been proven for strains belonging to L. rhamnosus, L. paracasei, and L. casei [38] in accordance with $\mathrm{FAO} / \mathrm{WHO}[38]$.

KCC-51 and KCC-52 showed good antibacterial and potential probiotic properties; next, we studied the impact of these strains on nutrient profiles, fermentative acids, and microbial changes in the ensiled silages at day 180. It suggested that the addition of KCC-51 and KCC-52 to forage samples when ensiling 
process enhanced acidification of triticale silages at both high and low moisture by increasing lactic acid concentration. Generally, enhancement of acidification is closely associated with the preservation of the ensiled silages. An addition of LAB at ensiling is intended to ensure rapid and fermentation of silages as it results in faster accumulation of lactic acid, reduced $\mathrm{pH}$ ranges at both high, and low moisture of ensiled silages which makes an unfavorable condition for enterobacterial growth $[39,40]$. Many reports suggested the advantage of LAB as inoculants for silage production which can utilize the water-soluble carbohydrates and convert into a lactic acid level, it is a major and important acid in the fermented silages and also a key marker of the preserved high quality silages [41,42]. LAB, particularly lactobacillus $s p$. in the plants, is not sufficient to induce expected fermentation rates when ensiled silages resulted in higher $\mathrm{pH}$, which is favorable for the undesirable microbial growths [43]. In the present study, non-inoculated silages of both low and high moistures had low numbers of LAB with high numbers of other epiphytic bacteria and yeast counts, while KCC-51 and KCC-52 treated silages had a higher population of LAB with lower counts of yeast which indicates the addition of inoculants dominated the growth of other epiphytic bacteria other than LAB. As evidenced that the LAB shared a higher percentage of the population in the total bacteria compared to non-inoculated silages. Successful fermentation indicates the disappearance of enterobacteria and the dominant growth of LAB in the silages. These changes are closely associated with the decline of $\mathrm{pH}$ and lactic acid production in inoculants applied silages [44]. The addition of L. rhamnosus rapidly drops the $\mathrm{pH}$ of the silages and inhibited fungal growth and mycotoxin production $[39,45,46]$. Additionally, L. paracasei and L. rhamnosus could be considered as excellent additives for plant based silage production with enriched nutrients for ruminant and non-ruminants [20-22].

The preservation of ensiled forage samples for prolonged periods is based on the strong acidification by the microbial inoculants. Faster acidification inactivates proteolytic enzymes activities and controls the diversity and richness of enterobacteria which grow until low $\mathrm{pH}$ reached [47]. Reduction of $\mathrm{pH}$ is generally used to monitor the silage quality and the ranges between 3.8 to 4.2 are desired for a successful ensiling [41]. In the current study, higher $\mathrm{pH}$ was noted in non-inoculated silages at both high and low moistures condition. Higher acidification was noted in the silages treated with KCC-51 and KCC-52. It confirmed that it was unable to induce the fermentation process of silages by epiphytic bacteria found naturally in the plants, therefore, required efficient inoculants to promote the fermentation process in the silages. Lactic acid, acetic acid, and butyric acid have been considered as key acids in the ensiled silages and represent the highest level of acids produced from WSC by LAB $[48,49]$, especially the lactic acid found higher in silages among the others acids, which contributed to reduce the $\mathrm{pH}$ of silages and prevent the undesirable microbial growths [50]. Low lactic acid and higher butyric acid were noted in non-inoculated silages which indicated lower lactic acid content and could not be able to dominate the other microbial growth resulted in poor fermentation. Acetic acid and butyric acid are the primary negative indicators of ensiled silages that reduced the dry matter content and energy during fermentation [43]. Addition of inoculants reduced butyric acid content of silages, at the same time slight increases of acetic acid were noted in the silages treated with KCC-51 and KCC-52. Many reports claimed that the moderate amount of acetic acid production plays a major role in the preservation of silages by its antimicrobial potential $[6,47,51]$.

\section{Conclusions}

KCC-51 and KCC-52 showed significant antibacterial activities against various pathogenic bacteria. Besides, these strains survived in the harsh condition of GIT; it confirmed its probiotic features. Furthermore, the addition of KCC-51 and KCC-52 showed a positive impact on the fermentation of both high and low moistures silages of triticale by enriching the nutrient content particularly, higher lactic acid with lower butyric acid concentration. Increased lactic acid bacteria in KCC-51 and KCC-52 inoculated silages, whereas reduced yeast counts compared to non-inoculated silages. Additionally, KCC-51 and KCC-52 treatment rapidly reduced the $\mathrm{pH}$ of silages than the control; it inhibits the undesirable microbial growths. Overall data suggested that the L. rhamnosus -51 and L. paracasei-52 
could be considered as potent inoculants used for silage production. A detailed investigation is needed to confirm the efficiency LAB based triticale silage from different cultivars at different stages and must study the effectiveness of triticale silages on animal performance.

Supplementary Materials: The Supplementary Materials are available online at http://www.mdpi.com/2076-3417/ 10/21/7855/s1.

Author Contributions: Conceptualization, I.S., D.K., and K.C.C.; methodology and validation, K.C.C., H.J.L., O.-K.H., and I.S.; formal analysis, K.M., and S.P.; resources, H.J.L. and O.-K.H.; writing-original draft preparation, I.S.; review and editing S.P., D.K.; and K.M.; supervision and funding acquisition, K.C.C. All authors have read and agreed to the published version of the manuscript.

Funding: This work was performed with the support of the Cooperative Research Program for Agriculture Science and Technology Development (Project title: Technique development for manufacture and quality improvement of triticale silage; Project No. PJ01339401), Rural Development Administration, Korea. This study was supported by a 2018 Postdoctoral Fellowship Program of the National Institute of Animal Science, Rural Development Administration and Korea.

Conflicts of Interest: The authors declare no conflict of interest

\section{References}

1. Fabiszewska, A.U.; Zielińska, K.J.; Wróbel, B. Trends in designing microbial silage quality by biotechnological methods using lactic acid bacteria inoculants: A minireview. World J. Microbiol. Biotechnol. 2019, 35, 76. [CrossRef] [PubMed]

2. Borreani, G.; Tabacco, E.; Schmidt, R.J.; Holmes, B.J.; Muck, R.E. Silage review: Factors affecting dry matter and quality losses in silages. J. Dairy Sci. 2018, 101, 3952-3979. [CrossRef] [PubMed]

3. Oliveira, A.S.; Weinberg, Z.G.; Ogunade, I.M.; Cervantes, A.A.P.; Arriola, K.G.; Jiang, Y.; Kim, D.; Li, X.; Goncalves, M.C.M.; Vyas, D.; et al. Meta-analysis of effects of inoculation with homofermentative and facultative heterofermentative lactic acid bacteria on silage fermentation, aerobic stability, and the performance of dairy cows. J. Dairy Sci. 2017, 100, 4587-4603. [CrossRef] [PubMed]

4. Richard, M. Recent advances in silage microbiology. Agric. Food Sci. 2013, 22. [CrossRef]

5. Moselhy, M.A.; Borba, J.P.; Borba, A.E.S. Improving the nutritive value, in vitro digestibility and aerobic stability of Hedychium gardnerianum silage through application of additives at ensiling time. Anim. Feed Sci. Technol. 2015, 206, 8-18. [CrossRef]

6. Kung, L., Jr.; Shaver, R.D.; Grant, R.J.; Schmidt, R.J. Silage review: Interpretation of chemical, microbial, and organoleptic components of silages. J. Dairy Sci. 2018, 101, 4020-4033. [CrossRef] [PubMed]

7. Ben-Dov, E.; Shapiro, O.H.; Siboni, N.; Kushmaro, A. Advantage of using inosine at the 3' termini of $16 \mathrm{~S}$ rRNA gene universal primers for the study of microbial diversity. Appl. Environ. Microbiol. 2006, 72, 6902-6906. [CrossRef]

8. Müller, T.; Ulrich, A.; Ott, E.-M.; Müller, M. Identification of plant-associated enterococci. J. Appl. Microbiol. 2001, 91, 268-278. [CrossRef]

9. Hill, D.; Sugrue, I.; Tobin, C.; Hill, C.; Stanton, C.; Ross, R.P. The Lactobacillus casei Group: History and Health Related Applications. Front. Microbiol. 2018, 9, 2107. [CrossRef]

10. Toh, H.; Oshima, K.; Nakano, A.; Takahata, M.; Murakami, M.; Takaki, T.; Nishiyama, H.; Igimi, S.; Hattori, M.; Morita, H. Genomic Adaptation of the Lactobacillus casei Group. PLoS ONE 2013, 8, e75073. [CrossRef]

11. Judicial Commission of the International Committee on Systematics of Bacteria (JCICSB). The type strain of Lactobacillus casei is ATCC 393, ATCC 334 cannot serve as the type because it represents a different taxon, the name Lactobacillus paracasei and its subspecies names are not rejected and the revival of the name 'Lactobacillus zeae' contravenes Rules $51 \mathrm{~b}(1)$ and (2) of the International Code of Nomenclature of Bacteria. Opinion 82. Int. J. Syst. Evol. Microbiol. 2008, 58, 1764-1765. [CrossRef]

12. RossI, F.; Gatto, V.; SabattinI, G.; Torriani, S. An assessment of factors characterising the microbiology of Grana Trentino cheese, a Grana-type cheese. Int. J. Dairy Technol. 2012, 65, 401-409. [CrossRef]

13. Shi, T.; Nishiyama, K.; Nakamata, K.; Aryantini, N.P.D.; Mikumo, D.; Oda, Y.; Yamamoto, Y.; Mukai, T.; Sujaya, I.N.; Urashima, T.; et al. Isolation of Potential Probiotic Lactobacillus rhamnosus Strains from Traditional Fermented Mare Milk Produced in Sumbawa Island of Indonesia. Biosci. Biotechnol. Biochem. 2012, 76, 1897-1903. [CrossRef] [PubMed] 
14. Succi, M.; Tremonte, P.; Reale, A.; Sorrentino, E.; Grazia, L.; Pacifico, S.; Coppola, R. Bile salt and acid tolerance of Lactobacillus rhamnosus strains isolated from Parmigiano Reggiano cheese. Fems Microbiol. Lett. 2005, 244, 129-137. [CrossRef] [PubMed]

15. Coppola, R.; Succi, M.; Sorrentino, E.; Iorizzo, M.; Grazia, L. Survey of lactic acid bacteria during the ripening of Caciocavallo cheese produced in Molise. Lait 2003, 83, 211-222. [CrossRef]

16. Argyri, A.A.; Zoumpopoulou, G.; Karatzas, K.-A.G.; Tsakalidou, E.; Nychas, G.-J.E.; Panagou, E.Z.; Tassou, C.C. Selection of potential probiotic lactic acid bacteria from fermented olives by in vitro tests. Food Microbiol. 2013, 33, 282-291. [CrossRef]

17. Kim, J.-D. Antifungal Activity of Lactic Acid Bacteria Isolated from Kimchi Against Aspergillus fumigatus. Mycobiology 2005, 33, 210-214. [CrossRef]

18. Ortigosa, M.; Arizcun, C.; Irigoyen, A.; Oneca, M.; Torre, P. Effect of lactobacillus adjunct cultures on the microbiological and physicochemical characteristics of Roncal-type ewes'-milk cheese. Food Microbiol. 2006, 23, 591-598. [CrossRef] [PubMed]

19. Verdenelli, M.C.; Ghelfi, F.; Silvi, S.; Orpianesi, C.; Cecchini, C.; Cresci, A. Probiotic properties of Lactobacillus rhamnosus and Lactobacillus paracasei isolated from human faeces. Eur. J. Nutr. 2009, 48, 355-363. [CrossRef]

20. Additives, E.P.O.; Feed, P.O.S.U.I.A. Scientific Opinion on the safety and efficacy of Lactobacillus paracasei (DSM 16245) as a silage additive for all species. EFSA J. 2011, 9, 2363. [CrossRef]

21. Salimei, E.; Capilongo, V.; Simoni, A.; Peiretti, P.G.; Maglieri, C.; Romano, C.A.; Mannina, L.; Coppola, R.; Sorrentino, E. Lactobacillus rhamnosus as Additive for Maize and Sorghum Ensiling. J. Agric. Food Chem. 2007, 55, 9600-9607. [CrossRef] [PubMed]

22. Li, M.; Zi, X.; Zhou, H.; Lv, R.; Tang, J.; Cai, Y. Silage fermentation and ruminal degradation of cassava foliage prepared with microbial additive. AMB Express 2019, 9, 180. [CrossRef] [PubMed]

23. Guan, H.; Shuai, Y.; Yan, Y.; Ran, Q.; Wang, X.; Li, D.; Cai, Y.; Zhang, X. Microbial Community and Fermentation Dynamics of Corn Silage Prepared with Heat-Resistant Lactic Acid Bacteria in a Hot Environment. Microorganisms 2020, 8, 719. [CrossRef] [PubMed]

24. GlamoČLija, N.; StarČEviĆ, M.; Ćirić, J.; Sefer, D.; Glisic, M.; Baltic, M.; Markovic, R.; SpasiĆ, M.; GlamoČLija, Đ. The importance of triticale in animal nutrition. Ветеринарски Жуурнал РепубликеСрпске 2018, 18. [CrossRef]

25. Harper, M.T.; Oh, J.; Giallongo, F.; Roth, G.W.; Hristov, A.N. Inclusion of wheat and triticale silage in the diet of lactating dairy cows. J. Dairy Sci. 2017, 100, 6151-6163. [CrossRef]

26. Gill, K.; Omokanye, A. Spring Triticale Varieties Forage Yield, Nutrients Composition and Suitability for Beef Cattle Production. J. Agric. Sci. 2016, 8, 1. [CrossRef]

27. Hackl, W.; Pieper, B.; Pieper, R.; Korn, U.; Zeyner, A. Effects of ensiling cereal grains (barley, wheat, triticale and rye) on total and pre-caecal digestibility of proximate nutrients and amino acids in pigs. J. Anim. Physiol. Anim. Nutr. 2010, 94, 729-735. [CrossRef]

28. Derbal, N.; Benbelkacem, A.; Dib, Y. An effective increase in milk production through triticale feeding. Commun. Agric. Appl. Biol. Sci. 2014, 79, 153-157.

29. Soundharrajan, I.; Kim, D.; Kuppusamy, P.; Muthusamy, K.; Lee, H.J.; Choi, K.C. Probiotic and Triticale Silage Fermentation Potential of Pediococcus pentosaceus and Lactobacillus brevis and Their Impacts on Pathogenic Bacteria. Microorganisms 2019, 7, 318. [CrossRef]

30. Arasu, M.V.; Jung, M.-W.; Kim, D.H.; Ilavenil, S.; Jane, M.; Park, H.S.; Al-Dhabi, N.A.; Jeon, B.T.; Choi, K.C. Enhancing Nutritional Quality of Silage by Fermentation with Lactobacillus plantarum. Indian J. Microbiol. 2014, 54, 396-402. [CrossRef]

31. Petsuriyawong, B.; Khunajakr, N. Screening of probiotic lactic acid bacteria from piglet feces. Kasetsart J. Nat. Sci. 2011, 45, 245-253.

32. De Angelis, M.; Siragusa, S.; Berloco, M.; Caputo, L.; Settanni, L.; Alfonsi, G.; Amerio, M.; Grandi, A.; Ragni, A.; Gobbetti, M. Selection of potential probiotic lactobacilli from pig feces to be used as additives in pelleted feeding. Res. Microbiol. 2006, 157, 792-801. [CrossRef] [PubMed] 
33. Wang, L.; Zhang, H.; Rehman, M.U.; Mehmood, K.; Jiang, X.; Iqbal, M.; Tong, X.; Gao, X.; Li, J. Antibacterial activity of Lactobacillus plantarum isolated from Tibetan yaks. Microb. Pathog. 2018, 115, 293-298. [CrossRef] [PubMed]

34. Kizerwetter-Świda, M.; Binek, M. Assessment of potentially probiotic properties of Lactobacillus strains isolated from chickens. Pol. J. Vet. Sci. 2016, 19, 15-20. [CrossRef]

35. Piwat, S.; Sophatha, B.; Teanpaisan, R. An assessment of adhesion, aggregation and surface charges of Lactobacillus strains derived from the human oral cavity. Lett. Appl. Microbiol. 2015, 61, 98-105. [CrossRef]

36. Casarotti, S.N.; Penna, A.L.B. Acidification profile, probiotic in vitro gastrointestinal tolerance and viability in fermented milk with fruit flours. Int. Dairy J. 2015, 41, 1-6. [CrossRef]

37. Buriti, F.C.; Castro, I.A.; Saad, S.M. Viability of Lactobacillus acidophilus in synbiotic guava mousses and its survival under in vitro simulated gastrointestinal conditions. Int. J. Food Microbiol. 2010, 137, 121-129. [CrossRef] [PubMed]

38. Reale, A.; Di Renzo, T.; Rossi, F.; Zotta, T.; Iacumin, L.; Preziuso, M.; Parente, E.; Sorrentino, E.; Coppola, R. Tolerance of Lactobacillus casei, Lactobacillus paracasei and Lactobacillus rhamnosus strains to stress factors encountered in food processing and in the gastro-intestinal tract. LWT-Food Sci. Technol. 2015, 60, 721-728. [CrossRef]

39. Ilavenil, S.; Kim, D.H.; Srisesharam, S.; Kuppusamy, P.; Park, H.S.; Yoon, Y.H.; Kim, W.H.; Song, Y.G.; Choi, K.C. Application of customised bacterial inoculants for grass haylage production and its effectiveness on nutrient composition and fermentation quality of haylage. 3 Biotech 2017, 7, 321. [CrossRef]

40. Muck, R.E.; Nadeau, E.M.G.; McAllister, T.A.; Contreras-Govea, F.E.; Santos, M.C.; Kung, L. Silage review: Recent advances and future uses of silage additives. J. Dairy Sci. 2018, 101, 3980-4000. [CrossRef]

41. Ahmadi, F.; Lee, Y.H.; Lee, W.H.; Oh, Y.-K.; Park, K.; Kwak, W.S. Long-term anaerobic conservation of fruit and vegetable discards without or with moisture adjustment after aerobic preservation with sodium metabisulfite. Waste Manag. 2019, 87, 258-267. [CrossRef]

42. Hashemzadeh-Cigari, F.; Khorvash, M.; Ghorbani, G.R.; Ghasemi, E.; Taghizadeh, A.; Kargar, S.; Yang, W.Z. Interactive effects of molasses by homofermentative and heterofermentative inoculants on fermentation quality, nitrogen fractionation, nutritive value and aerobic stability of wilted alfalfa (Medicago sativa L.) silage. J. Anim. Physiol. Anim. Nutr. 2014, 98, 290-299. [CrossRef] [PubMed]

43. Nascimento Agarussi, M.C.; Gomes Pereira, O.; Paula, R.A.D.; Silva, V.P.D.; Santos Roseira, J.P.; Fonseca e Silva, F. Novel lactic acid bacteria strains as inoculants on alfalfa silage fermentation. Sci. Rep. 2019, 9, 8007. [CrossRef]

44. Merry, R.J.; Lowes, K.F.; Winters, A. Current and future approaches to biocontrol in silage. In Proceedings of the 8th International Symposium Forage Conservation; Research Institute of Animal Nutrition: Pohorelice, Czech Republic, 1997; pp. 17-27.

45. Dogi, C.A.; Fochesato, A.; Armando, R.; Pribull, B.; de Souza, M.M.; da Silva Coelho, I.; Araújo de Melo, D.; Dalcero, A.; Cavaglieri, L. Selection of lactic acid bacteria to promote an efficient silage fermentation capable of inhibiting the activity of Aspergillus parasiticus and Fusarium gramineraum and mycotoxin production. J. Appl. Microbiol. 2013, 114, 1650-1660. [CrossRef]

46. Luz, C.; Ferrer, J.; Mañes, J.; Meca, G. Toxicity reduction of ochratoxin A by lactic acid bacteria. Food Chem. Toxicol. 2018, 112, 60-66. [CrossRef]

47. Muck, R.E. Silage microbiology and its control through additives. Rev. Bras. Zootec. 2010, 39, $183-191$. [CrossRef]

48. Li, P.; Zhang, Y.; Gou, W.; Cheng, Q.; Bai, S.; Cai, Y. Silage fermentation and bacterial community of bur clover, annual ryegrass and their mixtures prepared with microbial inoculant and chemical additive. Anim. Feed Sci. Technol. 2019, 247, 285-293. [CrossRef]

49. Yang, L.; Yuan, X.; Li, J.; Dong, Z.; Shao, T. Dynamics of microbial community and fermentation quality during ensiling of sterile and nonsterile alfalfa with or without Lactobacillus plantarum inoculant. Bioresour. Technol. 2019, 275, 280-287. [CrossRef] 
50. Kung, L.; Shaver, R. Interpretation and use of silage fermentation analysis reports. Focus Forage 2001, 3, 1-15.

51. Danner, H.; Holzer, M.; Mayrhuber, E.; Braun, R. Acetic acid increases stability of silage under aerobic conditions. Appl. Environ. Microbiol. 2003, 69, 562-567. [CrossRef]

Publisher's Note: MDPI stays neutral with regard to jurisdictional claims in published maps and institutional affiliations.

(C) 2020 by the authors. Licensee MDPI, Basel, Switzerland. This article is an open access article distributed under the terms and conditions of the Creative Commons Attribution (CC BY) license (http://creativecommons.org/licenses/by/4.0/). 